\title{
Distribution of Pseudomonas sp. populations in relation to maize root location and growth stage
}

\author{
C. Di Battista-Leboeuf, E. Benizri*, G. Corbel, S. Piutti, A. Guckert \\ UMR Agronomie et Environnement ENSAIA-INRA-INPL, 2 avenue de la Forêt de Haye, BP 172, 54500 Vandœuvre-lès-Nancy, France
}

(Received 25 June 2002; accepted 4 December 2002)

\begin{abstract}
The distribution of Pseudomonas sp. populations of the maize rhizosphere in relation to root location and growth stage was investigated using an agar plate method on TSA medium and on a selective medium S1, and a molecular approach on the 16S rDNA followed by restriction enzyme analysis ARDRA. Maize was cultivated on soil for 15 and 30 days. The root system was divided into three parts: the root tip, the root hair and the ramification zones. After 15 days of plant growth, Pseudomonas sp. were only localized on the root tips and on the roots close to the plant stem. No Pseudomonas were detected in the maize root hair zone. After Day 30, Pseudomonas sp. were recorded on the root tips, but also on the medium part of the root system. After amplification and restriction with the endonuclease Hinfl, the 212 bacteria isolated from the different root parts were distributed into 5 major ARDRA ribotypes. The evolution of these 5 groups was analyzed. At Day 15, the 5 major ARDRA ribotypes are well represented, whereas all the isolates are gathered into only 3 major ribotypes at Day 30 . The ribotypes ARDRA 1 and ARDRA 3 at 15 days persist and the number of strains belonging to these ARDRA ribotypes increases until Day 30 . In contrast, the number of strains belonging to ribotype ARDRA 2 decreases and ribotype ARDRA 4 disappears. Ribotype ARDRA 1 is present in all root sections (except in the root hair zone at Day 15) and during all the growth stages. The diversity of the isolates at Day 30 appeared to be lower than at the first growth stage in all root zones. These shifts along the root system were related to a variation of the nature and the quantity of maize exudates along the root system and during growth.
\end{abstract}

rhizosphere / maize / Pseudomonas / diversity / 16S rDNA / ARDRA

Résumé - Distribution des populations de Pseudomonas en relation avec la zone racinaire et le stade de développement du maïs. Nous avons déterminé le nombre total de bactéries cultivables sur milieu TSA ainsi que la densité des Pseudomonas sur milieu sélectif S1, ceci dans différents compartiments racinaires de maïs et en sol nu, à deux dates de récolte. Il en ressort que les populations de Pseudomonas ont une densité plus élevée dans la rhizosphère de maïs que dans le sol nu. De plus, ces densités augmentent fortement entre 15 et 30 jours, au niveau de la zone d'élongation et des poils absorbants. Les différentes souches isolées nous ont permis de constituer un souchier de 212 souches caractérisées par la technique ARDRA (amplification de la région 16S de l'ADNr et restriction enzymatique par l'enzyme HinfI). Les souches analysées se répartissent en 5 groupes ARDRA. La structure des populations de Pseudomonas sp. a été modifiée selon les zones racinaires étudiées et au cours du temps.

rhizosphère / maïs / Pseudomonas / diversité / 16S rDNA / ARDRA

\section{INTRODUCTION}

The rhizosphere is the volume of soil adjacent to and influenced by the plant [25]. Roots are known to excrete several forms of organic materials. The amounts and composition of these organic materials are different according to plant species and cultivars, and change during plant development $[5,21,33]$. As a result, the bacterial communities in the rhizosphere, which can use these organic materials as a substrate, would differ in composition and density [5, 8]. This may result in the buildup of a microflora specific to a particular plant species and genotype as well as to stages in the plant development.

With the growing interest in the introduction of plant growth-promoting microorganisms into the rhizosphere, it becomes of particular importance to characterize better the bacterial species naturally associated with the root system. Among the non-symbiotic rhizobacteria, much attention has 
been given to Pseudomonas sp. [29]. Specific Pseudomonas sp. strains are able to increase crop yields significantly and this increase is related to the promotion of plant growth and to the plant protection against pathogenic microorganisms [12, 31]. In order to develop effective strategies for the delivery and maintenance of bacterial inoculants in association with the root system, it is essential to demonstrate whether there are differences in populations supported by different portions of the root system. To date, few studies address the diversity of bacterial populations isolated from the different root system portions $[7,13,50]$.

In this study we aimed to obtain a better understanding of root part effects on the total bacterial community in soil and to determine the structure between populations of Pseudomonas sp. associated with maize roots. Pseudomonas sp. populations isolated at two plant growth stages from distinct morphological portions of the maize root system and from bulk soil were compared. The Pseudomonas species are characterized by an extraordinary nutritional versatility that favors the ability to colonize highly different habitats, among which are soil and plant rhizospheres [4, 30]. Knowledge of the structure of bacterial populations and how it changes with time is essential to understanding the mechanisms concerning the introduction of plant growth-promoting microorganisms into the rhizosphere.

\section{MATERIALS AND METHODS}

\subsection{Isolation of Pseudomonas strains}

Maize plants (Zea mays) were grown under non-sterile conditions. Seeds (cv. DEA, Pioneer France, weight 0.28$0.30 \mathrm{~g}$, not treated with fungicide) were sown in circularsection pots $(17 \mathrm{~cm}$ diameter, $21 \mathrm{~cm}$ height) containing a mixture of an agricultural soil and sand (2:1). The composition of the soil was as follows: $42.6 \%$ silt; $12.8 \%$ clay; $44.6 \%$ sand; $\mathrm{pH}=6.5$. This soil was first sieved $(5 \mathrm{~mm})$ and dried, together with the sand $(2 \mathrm{~mm})$, in a greenhouse $\left(20^{\circ} \mathrm{C}\right)$. The pots received the same amount of dry sand-soil mixture $(4 \mathrm{~kg})$ and were flooded overnight. The medium weight of the pots after draining gave the amount of water corresponding to $100 \%$ of the soil water holding capacity. The pots were maintained in the greenhouse for 6 weeks (to ensure microbial reactivation) and regularly checked for distilled water adjustment to $70 \%$ of the soil water holding capacity. Maize seeds ( 1 per pot) were sown at a depth of $2 \mathrm{~cm}$ after this 6 -week period. The control treatment consisted of pots without plants, stored in the same conditions. The pots were then transferred to an environmental growth chamber (photoperiod $16 \mathrm{~h}$, temperature $19^{\circ} \mathrm{C}$ night and $22{ }^{\circ} \mathrm{C}$ day, relative humidity $65 \%$, PPFD $350 \mu \mathrm{mol} \cdot \mathrm{m}^{-2} \cdot \mathrm{s}^{-1}$ ) for 30 days. Three plants were collected randomly at each sampling, i.e. 15 and 30 days of plant growth; corresponding to the end of the germination and elongation stages. The pots without plants, as controls, were also collected at the same time.

At each sampling, the root systems were removed from the pots without disturbing the soil. The seminal roots were divided into three portions: the ramification zone with secondary roots, the root hair-elongation zone and finally, the root tips. For each zone, the roots and the adhering soil were placed in flasks containing $100 \mathrm{ml}$ of PBS $(8 \mathrm{~g} \mathrm{NaCl}, 1.44 \mathrm{~g}$ $\mathrm{Na}_{2} \mathrm{HPO}_{4}, 0.24 \mathrm{~g} \mathrm{KH}_{2} \mathrm{PO}_{4}$ per liter, $\mathrm{pH}=7.2$ ). After dispersion of the adhering soil, the root portions were removed. The flasks were placed on an orbital shaker $(120 \mathrm{rpm})$ for $10 \mathrm{~min}$ and centrifuged $\left(750 \mathrm{rpm}, 10 \mathrm{~min}, 5^{\circ} \mathrm{C}\right)$. For the controls, $10 \mathrm{~g}$ of fresh weight of soil were also dropped into a flask containing $100 \mathrm{ml}$ of the phosphate buffer. Serial dilutions of these suspensions were plated on $0.1 \times$ Trypsic Soy Agar (TSA) amended with $12 \mathrm{~g} \cdot \mathrm{l}^{-1}$ agar for the enumeration of total culturable bacteria and on S1 (18 g agar, $10 \mathrm{~g}$ saccharose, $10 \mathrm{ml}$ glycerol, $2.3 \mathrm{~g} \mathrm{~K}_{2} \mathrm{HPO}_{4}, 5 \mathrm{~g}$ Caseine, $1 \mathrm{~g} \mathrm{NaHCO} 3,1 \mathrm{~g}$ $\mathrm{MgSO}_{4} 7 \mathrm{H}_{2} \mathrm{O}$ per liter) for the enumeration of Pseudomonas sp. [16]. S1 and $0.1 \times \mathrm{TSA}$ plates were incubated at $26{ }^{\circ} \mathrm{C}$ for $72 \mathrm{~h}$.

Bacterial isolation was always performed with samples diluted to the same level, i.e. one-hundred-fold dilutions from S1 plates with 30-100 colonies. Isolates were subjected to single-colony isolation on $\mathrm{S} 1$ medium and cryopreserved at $-80{ }^{\circ} \mathrm{C}$ in $40 \%$ glycerol.

\subsection{DNA extraction}

Bacterial cells were grown for $24 \mathrm{~h}$ at $26^{\circ} \mathrm{C}$ in YG medium (yeast extract $5 \mathrm{~g} \cdot \mathrm{l}^{-1}$, glucose $10 \mathrm{~g} \cdot \mathrm{l}^{-1}$ ). One-and-a-half $\mathrm{ml}$ of bacterial cell suspension was centrifuged $(3000 \mathrm{rpm})$ for $10 \mathrm{~min}$. The supernatant was discarded and DNA from the bacterial pellet was extracted by a rapid method using Proteinase K/CTAB and phenol/chloroform [23]. The DNA was resuspended in $50 \mu \mathrm{L}$ of sterile distilled water and stored at $-20^{\circ} \mathrm{C}$ until use.

\subsection{ARDRA}

DNA coding for the $16 \mathrm{~S}$ rRNA of each isolate was amplified with primers R (5'-CTACGGCTACCTTGTTACGA-3') and $F$ (5'-GAGAGTTTGATCCTGGCTCAG-3'). These primers were designed on the basis of the conserved bacterial sequences at the 5' and 3' ends of the 16S rRNA gene (Eurogentec, France; positions $27 \mathrm{f}$ and 1492 r, respectively, on Escherichia coli rDNA), which allowed amplification of almost the entire gene. PCR reactions were done in a total reaction volume of $25 \mu \mathrm{l}$ containing $2.5 \mu \mathrm{l}$ of Taq polymerase buffer 10X, $200 \mu \mathrm{M}$ of each dNTP, $1.5 \mathrm{mM} \mathrm{MgCl} 2,0.5 \mu \mathrm{M}$ of each primer, $0.625 \mathrm{U}$ Taq polymerase and $1 \mu \mathrm{l}$ of DNA template. The thermal cycling parameters (Gene cycler, Biorad) used were an initial denaturation at $94{ }^{\circ} \mathrm{C}$ for $3 \mathrm{~min}$, followed by 35 cycles of denaturation at $94{ }^{\circ} \mathrm{C}$ for $1 \mathrm{~min}$, annealing at $52{ }^{\circ} \mathrm{C}$ for $1.30 \mathrm{~min}$, and extension at $72{ }^{\circ} \mathrm{C}$ for $2 \mathrm{~min}$, with a final extension at $72{ }^{\circ} \mathrm{C}$ for $10 \mathrm{~min}$.

$5 \mu \mathrm{l}$ of the amplified $16 \mathrm{~S}$ was analyzed by $0.8 \%$ agarose (Quantum, France) gel electrophoresis in TBE (Tris-borateEDTA) buffer. Gels were stained using ethidium bromide $\left(10 \mathrm{mg} \cdot \mathrm{l}^{-1}\right)$ and photographed under U.V. light.

\subsection{Restriction digest and electrophoresis}

$5 \mu \mathrm{l}$ of the amplified $16 \mathrm{~S}$ was digested with the endonuclease HinfI, or the mix Alu I/MspI according to the manufacturer's instructions (Appligene, France). The restriction products were analyzed by $8.0 \%$ acrylamide gel electrophoresis 


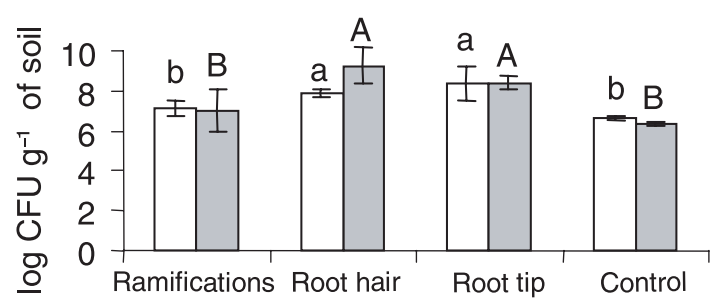

Figure 1. Densities of culturable bacteria in the ramification zone, root hair zone, apex and control soil of 15-day-old (white) and 30day-old (grey) maize. Results are expressed in log CFU per gram soil dry weight. Means $(\mathrm{n}=3)$ with different letters are significantly different at $P<0.05$.

(PAGE) [41] and mini protean III Cells (Biorad, France). Phage X174-DNA digested by HaeIII was used as a size standard. Gels were stained using ethidium bromide and photographed under U.V. light.

\subsection{Statistical analysis}

The log-transformed CFU data were analyzed by analysis of variance (ANOVA one way, STATBOX software, Grimmer Logiciels, 1997, Paris FRANCE).

\section{RESULTS}

\subsection{Colonization of maize root by total culturable bacteria and Pseudomonas sp.}

After 15 days of plant growth, most bacteria were recorded on the root tips and on the root hair-elongation zone (log CFU close to 8) (Fig. 1). Total growing bacteria showed similar population densities in the two other zones: the bacterial densities supported by the ramification zone and bulk soil are not significantly different (log CFU close to 7) but significantly lower than the density measured at the root tip and root hairelongation zone. At Day 30, culturable bacteria showed the same distribution along the root system as that observed at the first sampling date. Most bacteria were also recorded on the root tips and on the root hair-elongation zone and the densities observed in these two zones were significantly higher than those supported by the ramification zone and bulk soil.

Pseudomonas isolation was also performed with samples diluted to the same level, i.e. one-hundred-fold dilutions from S1 plates. Pseudomonas sp. grown on the specific S1 medium followed a different colonization pattern. After 15 days of plant growth, most Pseudomonas sp. were localized only on the root tips and on the roots close to the plant stem (respectively, $\log$ CFU close to 8 and 6). At the first sampling date, no Pseudomonas were detected in the maize root hair zone and in control soil. After 30 days of plant growth, most Pseudomonas sp. were recorded on the root tips, but also on the medium part of the root system; the root hair-elongation zone. An uneven distribution of Pseudomonas sp. was observed in the maize root system during plant growth

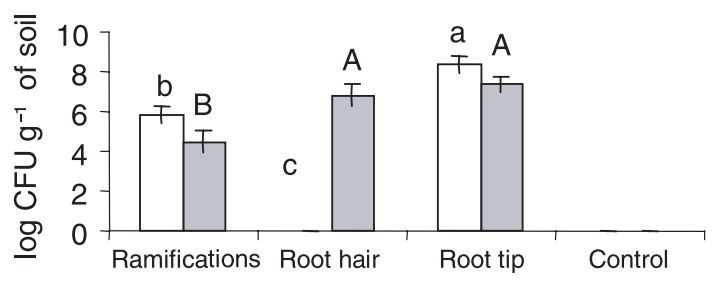

Figure 2. Densities of Pseudomonas sp. in the ramification zone, root hair zone, apex and control soil of 15-day-old (white) and 30-day-old (grey) maize. Results are expressed in log CFU per gram soil dry weight. Means $(n=3)$ with different letters are significantly different at $P<0.05$.

(Fig. 2). Moreover, at each sampling, no Pseudomonas was detected in control soil.

\subsection{Bacterial community waves by molecular analysis}

Total DNA was extracted from each strain isolated on S1 medium. The percentage of amplification was very high (about 95\%). A total of 212 colonies were isolated and analyzed.

After amplification, no differences were seen between the different isolates. PCR amplification of 16S rDNA of each of the 212 isolates resulted in a fragment (data not shown) of about $1500 \mathrm{pb}$. After restriction with the mix AluI/MspI, one major pattern was obtained. $95 \%$ of the strains belong to the same AluI/MspI ribotype. The endonuclease HinfI was then used. Restriction analysis of the amplified DNA of each sample with the enzyme HinfI allowed us to distinguish 5 ribotypes named ARDRA 1 to ARDRA 5 with a sixth group containing all the complex patterns different from the 5 ARDRA ribotypes. These 5 major ribotypes (ARDRA 1 to ARDRA 5) contained $96 \%$ of the isolates and the complex patterns are weakly represented. The number of strains belonging to ARDRA/HinfI ribotypes, isolated at the two sampling dates from the different parts of the root system, are presented in Table I.

\subsection{Distribution of Pseudomonas populations according to growth stage and along the root system}

In the bulk soil, there are very few isolates which are distributed into 3 different ribotypes belonging to the 5 major ARDRA ribotypes. The number of isolates were higher in the different root parts of the maize than in the bulk soil.

During growth, the distribution of the ARDRA ribotypes changes for each root zone. At Day 15, the 5 major ARDRA ribotypes are well represented, whereas all the isolates were gathered into only 3 major ribotypes at Day 30 (Tab. I). The ribotypes ARDRA 1 and ARDRA 3 at 15 days persist and the number of strains belonging to these ARDRA ribotypes increases until Day 30. In contrast, the number of strains belonging to ribotype ARDRA 2 decreases and ribotype ARDRA 4 disappears (respectively, $1.3 \%$ and $0 \%$ at Day 30 instead of $16 \%$ and $10 \%$ at Day 15). The ribotype ARDRA 4 disappears despite the higher number of total culturable bacteria at the second growth stage. Ribotype ARDRA 1 is 
Table I. Number of strains (relative distribution in brackets) belonging to ARDRA/HinfI ribotypes at the two sampling dates and from the different root zones.

\begin{tabular}{lcccccccccc}
\hline & Root & Tips & Root hair & Zone & Ramification & Zone & Control & $\begin{array}{c}\text { Soil } \\
\text { Sotal in }\end{array}$ & $\begin{array}{c}\text { Rhizosphere } \\
\text { soil }\end{array}$ \\
\hline Ribotype & Day 15 & Day 30 & Day 15 & Day 30 & Day 15 & Day 30 & Day 15 & Day 30 & Day 15 & Day 30 \\
ARDRA 1 & $4(12.5)$ & $40(49.4)$ & $0(0)$ & $38(92.7)$ & $1(6.25)$ & $18(48.7)$ & $1(33.33)$ & $0(0)$ & $5(10)$ & $96(60.4)$ \\
ARDRA 2 & $2(6.2)$ & $0(0)$ & $1(50)$ & $0(0)$ & $5(31.25)$ & $2(5.4)$ & $0(0)$ & $0(0)$ & $8(16)$ & $2(1.3)$ \\
ARDRA 3 & $3(9.4)$ & $2126)$ & $0(0)$ & $2(4.9)$ & $2(12.5)$ & $4(10.8)$ & $0(0)$ & $0(0)$ & $5(10)$ & $27(17)$ \\
ARDRA 4 & $3(9.4)$ & $0(0)$ & $0(0)$ & $0(0)$ & $2(12.5)$ & $0(0)$ & $0(0)$ & $0(0)$ & $5(10)$ & $0(0)$ \\
ARDRA 5 & $17(53.1)$ & $18(22.2)$ & $0(0)$ & $1(2.4)$ & $6(37.5)$ & $12(32.4)$ & $1(33.33)$ & $0(0)$ & $23(46)$ & $31(19.5)$ \\
Diverse & $3(9.4)$ & $2(2.4)$ & $1(50)$ & $0(0)$ & $0(0)$ & $1(2.7)$ & $1(33.33)$ & $0(0)$ & $4(8)$ & $3(1.8)$ \\
Total 212 & $32(100)$ & $81(100)$ & $2(100)$ & $41(100)$ & $16(100)$ & $37(100)$ & $3(100)$ & $0(100)$ & $50(100)$ & $156(100)$ \\
\hline
\end{tabular}

present in all root sections (except in the root hair zone at Day 15) and during all the growth stages (Tab. I). Moreover, its proportion increases at Day 30 and represents $60.4 \%$ of the patterns.

By dividing the number of different patterns by the total number of strains, the diversity in the root tips for samples was 0.19 at Day 15 and 0.05 at Day 30. The diversity of the isolates at Day 30 appeared to be lower than at the first growth stage. Similar results were obtained by analyzing the results in the other root zones.

We also observed a variable repartition of the same ribotype along the 4 zones and the 5 ribotypes were highly represented in the root tip part of the maize root and in the ramification zone. Moreover, over time, the number of strains belonging to ribotype ARDRA 1 showed an increase.

\section{DISCUSSION}

Rhizosphere soil represents a region of intense microbial activity which is maintained at a high level because of the release of root exudates by plant roots [6]. Exudation is known to display quantitative and qualitative variations between different plant species, such as oil rape and maize [42], grass species [36], pea and tomato [48]. It has long been hypothesized that the diversity of microorganisms present in different plant rhizospheres, and especially their functional abilities, may be linked to these variations in exudates $[17,18,29]$. But exudation patterns also undergo changes with plant age and location along the root system. The preferential sites of exudation along the root system have long been identified; these differ depending on plant species and experimental design. Among the most frequently studied sites are the root apices of primary and lateral roots, the area just behind the root cap, the root hair zone and the point of emergence of lateral roots [8]. These exudation sites produce exudates which differ in terms of both quantity and composition, as is the case in maize [42], annual grass [26] and pea [46]. These spatial and temporal variations of carbon sources occurring within a root system could be the factors which probably influence the composition and structure of associated rhizosphere bacterial communities. As far as we know, there is a paucity of studies dealing specifically with this type of ecological frame.
So, the aim of this experiment was to study temporal changes in the diversity of Pseudomonas sp. populations in bulk and rhizosphere soils originating from distinct root portions along the maize root system. We hypothesized that differences between root compartments or developmental stages would be sustained by distinct rhizodeposition pools. The description of the Pseudomonas sp. population was carried out using a combination of two methods: an agar plate method on a selective medium S1, and a molecular bacterial population profiling method (16S rDNA) followed by restriction enzyme analysis ARDRA.

At Day 15, most Pseudomonas were recorded on the root tips and on the ramification zone. Chiarini et al. made the same observation in their study (sampling after 15 days of plant growth) concerning maize root colonization by Burkholderia cepacia [7]. At this stage of maize growth (the germination growth stage), a higher concentration of exudates is found in the ramification zone, presumably due to seed storage compounds [22]. Schilling et al. analyzed soluble root exudates of maize for distinct root parts [42]. They found that the basal part of roots (the ramification zone) delivered the highest contents of sugars while the root tip was characterized by the highest contents of carboxylic acids. Amino acids were present in both locations in the same proportions. The root apices of primary and lateral roots are also known to be major sites of rhizodeposition. The root tips were the first parts of roots which came into contact with microbes of the bulk soil. Pseudomonas sp. seemed to be able to utilize mucilage. In spite of the complex composition of these compounds: a matrix of polysaccharide fibrils $[14,15,20]$, this association of polymers seemed to be compatible with the fast development of high Pseudomonas sp. densities. But some authors also claim a rapid leakage of low-molecular compounds at the root tip [21]. This assumption has been recently accredited by a study using bacterial sensors of sucrose along the root system of an annual grass, Avena barbata [26]: sucrose was apparently most abundant in soil near the root tip. Moreover, this zone is characterized by a great number of dead cells: 4000 to 21000 dead cells per day (i.e. $4 \mu \mathrm{g} \mathrm{C} \cdot \mathrm{d}^{-1}$ ).

At Day 30 (the elongation growth stage), a different distribution of Pseudomonas sp. was observed in the maize root system. Most Pseudomonas sp. were recorded on the root tips but also on the medium part of the root system; the root 
hair zone. This result is in accordance with a study in which bioluminescence markers were used to detect Pseudomonas sp. in the rhizosphere [10]. A high level of luminescence was found in the root hair zone. This zone, just behind the apex, is thought to be an active source of rhizodeposition [8]. Indeed, carbon and nitrogen concentrations are generally high in the vicinity of root tips [34, 35, 45]. Recently, Chiarini et al. [7] observed that Burkholderia cepacia tended to colonize preferentially the terminal portion of roots in mature plants (after 70 days of growth). Since the apex can be considered as a moving source of nutrients, carboxylic acids and amino acids exuded at this location are likely to be found in the root hairelongation zone, provided they have not been degraded by microorganisms of the apex.

Of the various nucleic acid techniques used to estimate microbial community composition and diversity in complex habitats, the most useful is the determination of the sequences of 16S RNA (rRNA) genes [24, 47]. These molecules are composed of highly conserved regions and also of regions with considerable sequence variation [49]. This molecular technique proved to be very effective for discriminating between Pseudomonas species [1, 28, 39, 40]. The choice of the restriction enzyme used in this study was driven by the studies of Laguerre et al. [28] and Scortichini et al. [40], who showed that it was possible to discriminate between strains isolated at different times from different geographical areas and sites only with HinfI.

In our study, we observed for each ribotype that the percentage of repartition was different along the root system. The ribotype ARDRA 1 became dominant whatever the zone considered. We also observed that the Pseudomonas population structure was modified along the root system and between samplings. Rhizodeposits could be one of the factors responsible for the observed repartition of ARDRA ribotypes. It has been hypothesized $[9,50]$ that changes in root exudates' composition along roots affected the rhizosphere bacterial communities. The rhizosphere parameter often suggested as supporting these genetic modifications between root compartments is the organic carbon released by living roots [3]. Only a few studies specifically focused on the effect of quantitative and qualitative variation of organic carbon on bacterial communities $[19,27]$. But it is unrealistic to think that competition for nutriments (rhizodeposits) was the sole factor. For instance, spatial variation of $\mathrm{pH}$ along maize roots has been measured [37]. Root colonization and rhizosphere competence are also known to imply numerous microbial properties such as antibiotics synthesis, motility, chemotaxis, amino acids and vitamin B1 prototrophy, and the presence of the O-antigen of lipopolysaccharide, among the most studied factors [4, 32, 38].

Changes in genetic structure over time have often been described. Di Cello et al. [11] showed that populations of Burkholderia cepacia, isolated from the maize rhizosphere at five stages of development (between 3 to 18 weeks after planting), displayed a decreasing diversity over time, using ARDRA and RAPD. In our case, the diversity estimated by dividing the number of different patterns by the total of strains [44] also showed a decrease in each root zone over time. Indeed, the diversity of the isolates at Day 30 appeared to be lower than at the first growth stage.
Our aim was to measure the influence of time and maize root location on Pseudomonas population structure. We observed an uneven distribution of Pseudomonas cells between different root system portions. We hypothesized that potential differences could be assigned to differences in the availability of carbon resources. Indeed, it is conceivable that, among other factors, root exudates may play an important role, as it is known that spatial variation in soluble carbon sources along roots coincides with different trophic groups of bacteria $[2,43]$. At the genetic level the factor which probably alters the genetic diversity of Pseudomonas is also thought to be organic carbon, the availability and nature of which are known to vary with root location and over time. The present work sheds more light on the dynamics of a single bacterial species in the rhizosphere of maize and on the transformations it undergoes during plant development. More studies are required to understand the specific role of rhizodeposits (mucilage and exudates) in bacterial diversity.

Acknowledgements: This work was supported by the INSU-PNSE (National Soil Erosion Programme of CNRS, 99PNSE-30).

\section{REFERENCES}

[1] Achouak W., Sutra L., Heulin T., Meyer J.M., Framin N., Degrave S., Christen R., Gardan L., Pseudomonas brassicacearum sp. nov. and Pseudomonas thivervalensis sp. nov., two root-associated bacteria from Brassica napus and Arabidopsis thaliana, Int. J. Syst. Bacterial. Evol. Microbiol. 50 (2000) 9-18.

[2] Baudoin E., Benizri E., Guckert A., Metabolic structure of bacterial communities from distinct maize rhizosphere compartments, Eur. J. Soil Biol. 37 (2001) 85-93.

[3] Baudoin E., Benizri E., Guckert A., Impact of growth stage on the bacterial community structure along maize roots, as determined by metabolic and genetic fingerprinting, Appl. Soil Ecol. 19 (2002) 135-145.

[4] Benizri E., Baudoin E., Guckert G., Root colonization by inoculated plant growth-promoting rhizobacteria, Biocontrol Sci. Technol. 11 (2001) 557-574.

[5] Bowen G.D., Rovira A.D., Plant roots: the hidden half, in: Waisel Y., Eshel A., Kafkafi U. (Eds.), Marcel Dekker, New York, 1991, pp. 641-649.

[6] Bowen G.D., Rovira A.D., The rhizosphere and its management to improve plant growth, Adv. Agron. 66 (1999) 1-102.

[7] Chiarini L., Giovannelli V., Bevivino A., Dalmastri C., Tabacchioni S., Different portions of the maize root system host Burkholderia cepacia populations with different degrees of genetic polymorphism, Environ. Microbiol. 2 (2000) 111-118.

[8] Curl E.A., Truelove B., The rhizophere, Springer-Verlag, New York, 1986.

[9] Dalmastri C., Chiarini L., Cantale C., Bevivino A., Tabacchioni S., Soil type and maize cultivar affect the genetic diversity of maize root-associated Burkholderia cepacia populations, Microbiol. Ecol. 38 (1999) 273-284.

[10] De Weger L.A., Dunbar P., Mahafee W.F., Lugtenberg B.J.J., Sayler G.S., Use of bioluminescence markers to detect Pseudomonas spp. in the rhizosphere, Appl. Environ. Microbiol. 57 (1991) 3641-3644.

[11] Di Cello F., Bevivino A., Chiarini L., Fani R., Paffetti D., Tabacchioni S., Dalmastri C., Biodiversity of a Burkholderia cepacia population isolated from the maize rhizosphere at different plant growth stages, Appl. Environ. Microbiol. 63 (1997) 4485-4493. 
[12] Dowling D.N., O'Gara F., Metabolites of Pseudomonas involved in the biocontrol of plant disease, Trends Biotechnol. 12 (1994) 133-141.

[13] Duineveld B.M., Rosado A.S., Van Elsas J.D., Van Veen J.A., Analysis of the dynamics of bacterial communities in the rhizosphere of the chrysanthemum via denaturing gradient gel electrophoresis and substrate utilization patterns, Appl. Environ. Microbiol. 64 (1998) 4950-4957.

[14] Floyd R.A., Ohlrogge A.J., Gel formation on nodal root surfaces of Zea mays I: investigation of the gel's composition, Plant and Soil 33 (1970) 331-341.

[15] Foster R.C., The fine structure of epidermal cell mucilages of roots, New Phytol. 91 (1982) 727-740.

[16] Gould W.D., Hagedorn C., Bardinelli T.R., Zablotowicz R.M. New selective media for enumeration and recovery of fluorescent pseudomonads from various habitats, Appl. Environ. Microbiol. 49 (1985) 28-32.

[17] Grayston S.J., Campbell C.D., Functional biodiversity of microbial communities in the rhizosphere of hybrid larch (Larix eurolepsis) and Sitka spruce (Picea sitchensis), Tree Physiol. 16 (1996) 1031-1038.

[18] Grayston S.J., Wang S., Campbell C.D., Edwards A.C., Selective influence of plant species on microbial diversity in the rhizosphere, Soil Biol. Biochem. 30 (1998) 369-378.

[19] Griffiths B.S., Ritz K., Ebblwhite N., Dobson G., Soil microbial community structure: effects of substrate loading rates, Soil Biol. Biochem. 31 (1999) 145-153.

[20] Guckert A., Breisch H., Reisinger O., Interface sol-racine I : étude au microscope électronique des relations mucigel-argile-microorganismes, Soil Biol. Biochem. 7 (1975) 241-250.

[21] Hale M.G., Moore L.D., Griffin G.J., Root exudates and exudation, in: Dommergues Y.R., Krupa S.V. (Eds.), Interactions between non-pathogenic soil microorganisms and plants, Elsevier Scientific Publishing Company, Amsterdam - Oxford - New York, 1978, pp. 163-203.

[22] Hamlen R.A., Lukezic F.L., Bloom J.R., Influence of age and stage of development on the neutral carbohydrate components in root exudates from alfalfa plants grown in a gnotobiotic environment Can. J. Plant Sci. 52 (1972) 633-642.

[23] Henrion B., Le Tacon F., Martin F., Rapid identification of genetic variation of ectomycorrhizal fungi by amplification of ribosomal RNA genes, New Phytol. 122 (1992) 289-298.

[24] Hill G.T., Mitkowski N.A., Aldrich-Wolfe L., Emele L.R., Jurkonie D.D., Ficke A., Maldonado-Ramirez S., Lynch S.T., Nelson E.B., Methods for assessing the composition and diversity of soil microbial communities, Appl. Soil Ecol. 15 (2000) 25-36.

[25] Hiltner L., Über neuer Erfahrungen und Probleme auf dem Gebiet der Bodenbakteriologie unter besonderer Nerücksichtingung der Gründüngung und Brache, Arb. Deut. Landwirt. Ges. 98 (1904) 59-78.

[26] Jaeger C.H. III, Lindow S.E., Miller W., Clark E., Firestone M.K., Mapping of sugar and amino acid availability in soil around roots with bacterial sensors of sucrose and tryptophan, Appl. Environ. Microbiol. 65 (1999) 2685-2690.

[27] Kozdroj J., Van Elsas J.D., Response of the bacterial community to root exudates in soil polluted with heavy metals assessed by molecular and cultural approaches, Soil Biol. Biochem. 32 (2000) $1405-1417$.

[28] Laguerre G., Rigottier-Gois L., Lemanceau P., Fluorescent Pseudomonas species categorized by using polymerase chain reaction (PCR)/restriction fragment analysis of 16S rDNA, Mol. Ecol. 3 (1994) 479-487

[29] Latour X., Corberand T., Laguerre G., Allard F., Lemanceau P., The composition of fluorescent pseudomonad populations associated with roots is influenced by plant and soil type, Appl. Environ. Microbiol. 62 (1996) 2449-2456.
[30] Latour X., Lemanceau P., Métabolisme carboné et énergétique des Pseudomonas spp. fluorescents saprophytes à oxydase positive, Agronomie 17 (1997) 427-443.

[31] Lemanceau P., Effets bénéfiques des rhizobactéries sur les plantes : exemple des Pseudomonas spp. fluorescents, Agronomie 12 (1992) 413-437.

[32] Lugtengerg Ben J.J., Dekkers L.C., What makes Pseudomonas bacteria rhizosphere competent?, Environ. Microbiol. 1 (1999) 9-13.

[33] Lynch J.M., Whipps J.M., Substrate flow in the rhizosphere, Plant and Soil 129 (1990) 1-10.

[34] McCully M.E., Canny M.J., Localization of translocated ${ }^{14} \mathrm{C}$ in roots and root exudates of field-grown maize, Physiol. Plant. 65 (1985) 380-392.

[35] McDougall B.M., Rovira A.D., Sites of exudation of ${ }^{14} \mathrm{C}$ labelled compounds from wheat roots, New Phytol. 69 (1970) 999-1003.

[36] Morse C.C., Yevdokimov I.V., DeLuca T.H., In situ extraction of rhizosphere organic compounds from contrasting plant communities, Commun. Soil Sci. Plant Anal. 31 (2000) 725-742.

[37] Plassard C., Meslem M., Souche G., Jaillard B., Localization and quantification of net fluxes of $\mathrm{H}^{+}$along maize roots by combined use of $\mathrm{pH}$-indicator dye videodensitometry and $\mathrm{H}^{+}$-selective microelectrodes, Plant and Soil 211 (1999) 29-39.

[38] Rainey P.B., Adaptation of Pseudomonas fluorescens to the plant rhizosphere, Environ. Microbiol. 1 (1999) 243-257.

[39] Roos I.L., Alami Y., Harvey P.R., Achouak W., Ryder M.H., Genetic diversity and biological control activity of novel species of closely related pseudomonads isolated from wheat field soils in South Australia, Appl. Environ. Microbiol. 66 (2000) 1609-1615.

[40] Scortichini M., Marchesi U., Rossi M.P., Di Prospero P., Bacteria associated with Hazelnut (Corylus avellaba L.) decline are of two groups: Pseudomonas avellanae and strains resembling $P$. syringae pv. Syringae, Appl. Environ. Microbiol. 68 (2002) 476-484.

[41] Sambrook J., Fritsch E.F., Maniatis T., Molecular cloning: a laboratory manual, 2nd ed., Cold Spring Harbor Laboratory, Cold Sping Harbor, 1989.

[42] Schilling G., Gransee A., Deubel A., Lezovic G., Ruppel S., Phosphorus availability, root exudates, and microbial activity in the rhizosphere, Z. Pflanzenernähr. Bodenkd. 161 (1998) 465-478.

[43] Schippers B., Van Vuurde J.W.L., Studies of microbial colonization of wheat roots and manipulation of the microflora, in: Luotit M.W., Miles J.A.R. (Eds.), Microbial Ecology, Berlin, SpringerVerlag, 1978, pp. 295-298.

[44] Smit E., Leeflang P., Wernars K., Detection of shifts in microbial community structure and diversity in soil caused by copper contamination using amplified ribosomal DNA restriction analysis, FEMS Microbiol. Ecol. 23 (1997) 249-261.

[45] Trofymow J.A., Coleman D.C., Cambardella C., Rates of rhizodeposition and ammonium depletion in the rhizosphere of axenic oat roots, Plant and Soil 97 (1987) 333-344.

[46] Van Egeraat A.W.S.M., Exudation of ninhydrin-positive compounds by pea-seedling roots: a study of the sites of exudation and the composition of the exudates, Plant and Soil 42 (1975) 37-47.

[47] Ward D.M., Weller R., Bateson M.M., 16S rRNA sequences reveal numerous uncultured microorganisms in a natural community, Nature 345 (1992) 63-65.

[48] Whipps J.M., Carbon loss from the roots of tomato and pea seedlings grown in soil, Plant and Soil 103 (1987) 95-100.

[49] Woese C.R., Bacterial evolution, Microb. Res. 51 (1987) 221-271.

[50] Yang C.H., Crowley D.E., Rhizosphere microbial community structure in relation to root location and plant iron nutritional status, Appl. Environ. Microbiol. 66 (2000) 345-351. 